\title{
Spatial variation and evidence of multiple transport pathways for Dungeness crab Cancer magister late-stage larvae in southeastern Alaska
}

\author{
Quinn T. Smith ${ }^{1,2, *}$, Ginny L. Eckert ${ }^{1}$ \\ ${ }^{1}$ Juneau Center School of Fisheries and Ocean Sciences, University of Alaska Fairbanks, 17101 Point Lena Loop Rd., Juneau, \\ Alaska 99801, USA \\ ${ }^{2}$ Alaska Department of Fish and Game, Division of Commercial Fisheries, PO Box 110024, Juneau, Alaska 99811, USA
}

\begin{abstract}
The fate of early life stages can affect the spatial and temporal population dynamics of managed marine populations. Early Dungeness crab Cancer magister larval stages off the west coast of the contiguous United States migrate out of estuaries, develop on or beyond the continental shelf, and return to nearshore areas prior to settlement. Whether a similar ontogenetic movement pattern exists for C. magister larvae in southeastern Alaska is unknown. Extrapolation is difficult due to differences between the Alaska Coastal Current and California Current oceanographic domains and to the complex coastline, high-amplitude tides, and the large amount of freshwater influx in Alaska. We investigated the temporal and spatial variations in abundance and size of $C$. magister megalopae in the northern portion of southeastern Alaska. We found a high degree of spatial variation in the abundance of C. magister megalopae on both local $(2$ to $6 \mathrm{~km})$ and regional $(300+\mathrm{km}) \mathrm{scales}$. Although temporal differences were found among sites on a regional scale, there was no order in the arrival time of the pulse from the outer coast to the inside waters. The abundance of megalopae was higher in Icy Strait, which contained 3 out of 4 of the highest abundance sites, than at sites in Chatham Strait or Lynn Canal. Larvae varied in size and weight among these 3 regions. Due to spatial variation in abundance and larval size, as well as the lack of ordered pulse arrival times and the potentially isolating currents proposed by computer simulation, we propose multiple transport pathways for C. magister populations in northern southeastern Alaska.
\end{abstract}

KEY WORDS: Decapod larvae - Larval transport · Crustacea · Dispersal · Larval dynamics · Larval morphometrics $\cdot$ Recruitment $\cdot$ Marine reserves

\section{INTRODUCTION}

The distribution of early life stages of marine organisms with complex life histories can affect the spatial and temporal dynamics of adult populations (Botsford et al. 1998, 2001, Shanks \& Roegner 2007). Larval transport can regulate populations that are recruitment-limited (Yoshioka 1982, McConaugha 1988, Roughgarden et al. 1988, Broitman et al. 2008). Mechanisms of larval transport are complex and depend, among other factors, on larval behavior (Shanks 1986, Morgan \& Fisher 2010), oceanography (Shanks \& Eck- ert 2005, Morgan et al. 2009b), and life history (Shanks \& Eckert 2005, Olaguer-Feliú et al. 2010). The larval ecology of a number of species of commercially and ecologically important estuarine and nearshore benthic decapod crustaceans is quite well understood, including the Atlantic blue crab Callinectes sapidus (Morgan et al. 1996, Epifanio \& Tilburg 2008), American lobster Homarus americanus (Xue et al. 2008, Incze et al. 2010), and green crab Carcinus maenas (Queiroga et al. 1997). Life-history strategies for these species incorporate larval behaviors and oceanographic processes that serve to either retain larvae 
nearshore during development or export newly hatched larvae offshore, with subsequent zoeal development on the shelf and migration of late-stage or postlarvae back to shore or into estuaries.

Dungeness crab Cancer magister inhabit 2 primary oceanographic domains: a coastal upwelling system from Baja California to the northern tip of Vancouver Island (Parrish et al. 1981, Thomson et al. 1989), and a freshwater-influenced, coastal downwelling system from northern British Columbia to Alaska (Ware \& McFarlane 1989). Early C. magister zoeal stages off the west coast of the contiguous United States migrate out of estuaries and develop on or beyond the continental shelf, molt to the terminal larval (megalopae) stage, and rapidly return to nearshore areas prior to settlement in California (Reilly 1983, Shanks 1986), Oregon (Lough 1974, Johnson \& Shanks 2002, Miller \& Shanks 2004), Washington (Jamieson et al. 1989, Hobbs et al. 1992), and southern British Columbia (Orensanz \& Gallucci 1988). In contrast, C. magister larvae may be retained nearshore in Puget Sound (Orensanz \& Gallucci 1988, Debrosse et al. 1990, Dinnel et al. 1993). C. magister megalopae are strong swimmers, with forward movement of $8.5 \mathrm{~cm} \mathrm{~s}^{-1}$ in still water (Fernandez et al. 1994). This attribute is, however, insufficient to explain the ability of larvae to move offshore, to horizontal distances of at least $350 \mathrm{~km}$ (Jamieson \& Phillips 1988, Hobbs et al. 1992, Botsford et al. 1998, Eggleston et al. 1998, Johnson \& Shanks 2002). Variability in adult $C$. magister abundance has been tied to variability in abundance of megalopae by Shanks \& Roegner (2007), who found that during a $5 \mathrm{yr}$ sampling period $90 \%$ of the variation in catch of legal-size males from Oregon through central California was explained by the abundance of returning megalopae $4 \mathrm{yr}$ earlier in Coos Bay, Oregon. Variability in the abundance of megalopae was primarily influenced by variability in the timing of a transition in prevailing wind direction and the related transition in ocean surface transport from offshore to onshore. Thus, horizontal movements from and to shore are likely due to advection by wind or tidally driven currents, seasonal current shifts, or differences in water density (Shanks 1995a).

We examined spatial and temporal variations in Cancer magister late-stage larval abundance and size on both local (2 to $6 \mathrm{~km})$ and regional $(300+\mathrm{km})$ scales in the northern portion of southeastern Alaska. Whether larvae that originate in southeastern Alaska develop offshore or onshore in the Alaska Current region is unclear. Due to differences in oceanographic domains and to the complex network of waterways among numerous islands, high-amplitude tides, and large amounts of freshwater input, it cannot be assumed that $C$. magister larvae in southeastern Alaska have an offshore ontogenetic movement pat- tern, like those in the California Current system. Although the oceanography within southeastern Alaska is poorly understood, advection is generally northward, with great spatial heterogeneity in physical processes controlling local circulation (Weingartner et al. 2009). Populations of C. magister in southeastern Alaska are likely connected via larval dispersal to populations further south in British Columbia and possibly Washington (Park et al. 2007). Recent studies in Glacier Bay found that $C$. magister zoeae are produced in high numbers and are abundant in the early zoeal stages and then absent in later zoeal stages, which suggests that they are likely locally exported (Fisher 2006). Megalopae are found in high abundance several months later, suggesting that they subsequently reinvade the bay (Fisher 2006, Herter \& Eckert 2008).

It is unclear whether processes affecting larval behavior and supply in Glacier Bay are broadly applicable to greater southeastern Alaska, as Glacier Bay has different oceanography, habitat, and presently no fishing pressure. Thus, our goal was to compare spatial variation, spatio-temporal abundance, and morphometric variation in larvae over both small and large spatial scales to evaluate how representative Glacier Bay may be of the region. We hypothesized that the highly complex region would not have homogenous larval distribution and, therefore, that spatial variability on large and small scales would exist. We further hypothesized that if larval transport patterns are similar for Cancer magister along the west coast of the contiguous United States and southeastern Alaska, larvae would migrate onshore with a temporal lag of pulses of larvae among sites closer to the outer coast and sites farther inland, with larvae arriving at sites closer to the outer coast before sites farther away. Lastly, we hypothesized that if larval ontogenetic development and transport mechanisms are homogenous, then we would find no variation in larval size between study sites, as there would be no biotic or abiotic mechanism to cause a difference in their development or growth.

\section{MATERIALS AND METHODS}

Light-trap sampling. We sampled decapod larvae in southeastern Alaska using light traps of a similar design to those used by Porter et al. (2008). Light traps consisted of translucent $18.9 \mathrm{l}$ carboys with a funnel opening $(10 \mathrm{~cm}$ tapering to $0.8 \mathrm{~cm})$ on each side and a removable $250 \mu \mathrm{m}$ mesh bottom. Traps were illuminated $24 \mathrm{~h} \mathrm{~d}^{-1}$ by 2 Princeton Tec Attitude dive lights, each producing 12 lumen with 3 LEDs. Batteries were changed every other day to maintain lights at a constant intensity. All specimens were preserved in $80 \%$ ethanol; all brachyuran larvae were identified to fam- 
ily, and all cancrid crabs were identified to species (Lough 1974, Shanks 2001). Light traps of this design more effectively sample megalopae than plankton nets, but are not efficient zoeal samplers (Porter et al. 2008); therefore, we focus here on megalopae collected in the traps.

In 2005, we sampled at 3 sites in southern Berner's Bay: Echo Cove $\left(58.672^{\circ} \mathrm{N}, 134.920^{\circ} \mathrm{W}\right)$, Cowee Creek $\left(58.695^{\circ} \mathrm{N}, 134.943^{\circ} \mathrm{W}\right)$, and Sawmill Creek $\left(58.720^{\circ} \mathrm{N}\right.$, $134.947^{\circ} \mathrm{W}$ ) (Fig. 1) during September and October, the peak months of settlement for Cancer magister in southeastern Alaska (Eckert 2004). We established 3 replicate trap lines at haphazardly selected locations at each site along the $10 \mathrm{~m}$ mean lower low water (MLLW) depth contour with 2 light traps placed on each line, one within $1 \mathrm{~m}$ of the surface (hereafter 'surface traps') and one at $10 \mathrm{~m}$ depth and approximately $1 \mathrm{~m}$ from the bottom (hereafter 'bottom traps'). Echo Cove was sampled from 4 September to 30 October (except 22 October) $(\mathrm{n}=56 \mathrm{~d})$. Cowee Creek and Sawmill Creek were sampled from 4 September to 29 October (except 22, 24 and 27 October) $(n=53$ d). Spatial abundance in 2005 was compared between Berner's Bay and Bartlett Cove, Glacier Bay, using data from Herter \& Eckert (2008) that were collected using identical light-trap setups. Herter \& Eckert (2008) placed 3 light-trap lines in Bartlett Cove and sampled them daily (18 September to 30 October, $\mathrm{n}=41 \mathrm{~d}$ ).

In 2006, light traps were sampled daily in Echo Cove (Table 1, Fig. 1) from 1 September to 1 November (except 28 October, $\mathrm{n}=58 \mathrm{~d}$ ). Eight additional sites throughout northern southeastern Alaska (Table 1, Fig. 1), at varying distances from the outer coast, were sampled from 16 to 29 September $(n=14$ d), the expected period of peak abundance, to examine the spatial distribution of Cancer magister megalopae on a larger scale. These sites included Elfin Cove, Bartlett Cove, Gustavus, and Hoonah in Icy Strait; Little Port Walter and Angoon in Chatham Strait; and Indian Cove, Echo Cove, and Haines in Lynn Canal (Table 1, Fig. 1). At each site, 3 replicate traps were attached to floating docks within $1 \mathrm{~m}$ of the surface. Local volunteers from high schools, lodges, and governmental agencies sampled the light traps daily.

Spatial variation analyses. Daily abundance among the 3 sites in Berner's Bay in 2005 was examined using a 2-way ANOVA, with location and depth as factors. Variation in daily abundance between Echo Cove and Bartlett Cove in 2005 was examined using a repeated measures ANOVA, which is robust against autocorrelation in time series. In order to obtain a balanced design for the repeated measures analyses, days when all sites were not sampled were removed from the data set. We analyzed variation in daily abundance among the 9 sites sampled for $2 \mathrm{wk}$ in September 2006 with a 1 -way ANOVA on $\log _{10}$ (abundance + 0.1)-transformed data to reduce and normalize variance among daily abundance. We analyzed all data with SAS statistical software (v.9.1, SAS Institute). All test residuals, when available, were examined for assumption violations, and, if found, appropriate trans-

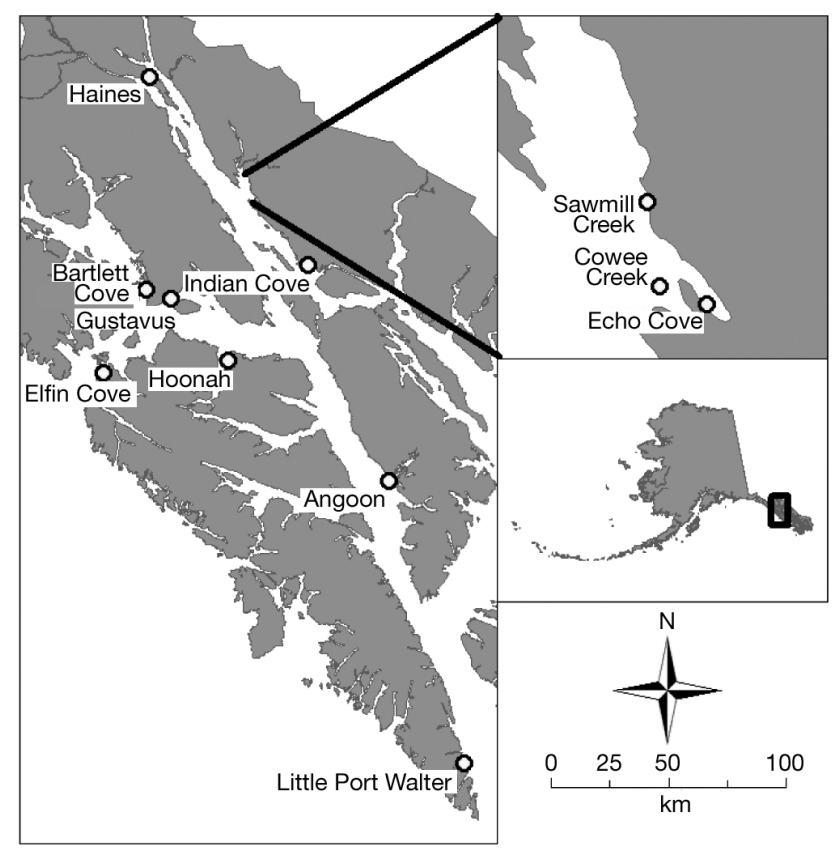

Fig. 1. Locations of the study sites sampled in the northern portion of southeastern Alaska, USA, in 2005 and 2006. For GPS coordinates, see Table 1

Table 1. Site locations sampled in September 2006. See Fig. 1 for site map. Distances from the outer coast measured along a water route. Region refers to the waterway in which the site is located

\begin{tabular}{|c|c|c|c|}
\hline Site & Coordinates & $\begin{array}{c}\text { Distance to } \\
\text { outer coast }(\mathrm{km})\end{array}$ & Region \\
\hline Elfin Cove & $58.195^{\circ} \mathrm{N}, 136.346^{\circ} \mathrm{W}$ & 18 & Icy Strait \\
\hline Bartlett Cove & $58.460^{\circ} \mathrm{N}, 135.880^{\circ} \mathrm{W}$ & 61.5 & Icy Strait \\
\hline Gustavus & $58.390^{\circ} \mathrm{N}, 135.730^{\circ} \mathrm{W}$ & 61 & Icy Strait \\
\hline Hoonah & $58.111^{\circ} \mathrm{N}, 135.448^{\circ} \mathrm{W}$ & 85 & Icy Strait \\
\hline Little Port Walter & $56.383^{\circ} \mathrm{N}, 134.648^{\circ} \mathrm{W}$ & 52 & Chatham Strait \\
\hline Angoon & $57.502^{\circ} \mathrm{N}, 134.582^{\circ} \mathrm{W}$ & 170 & Chatham Strait \\
\hline Indian Cove & $58.377^{\circ} \mathrm{N}, 134.700^{\circ} \mathrm{W}$ & $\begin{array}{c}296.5 \text { via Chatham, } \\
158 \text { via Icy }\end{array}$ & Lynn Canal \\
\hline Echo Cove & $58.672^{\circ} \mathrm{N}, 134.920^{\circ} \mathrm{W}$ & $\begin{array}{c}304 \text { via Chatham, } \\
183.5 \text { via Icy }\end{array}$ & Lynn Canal \\
\hline Haines & $59.235^{\circ} \mathrm{N}, 135.443^{\circ} \mathrm{W}$ & $\begin{array}{l}375 \text { via Chatham, } \\
234 \text { via Icy }\end{array}$ & Lynn Canal \\
\hline
\end{tabular}


formations were used. When results were significantly different, a Bonferroni post-hoc test was used to compare least-squared means for all effects.

Temporal variation analyses. We compared larval abundance in Echo Cove between 2005 and 2006 using 1-way ANOVA. Comparisons between Echo Cove (Berner's Bay) and Bartlett Cove (Glacier Bay) were conducted with repeated measures (as described above) and with correlation analysis, with diel lags of -5 to $+5 \mathrm{~d}$. For the larger scale analysis, we examined the abundance of megalopae at 6 of the 9 sites sampled in September 2006 using a 2-way repeated measures analysis with location and date as factors. Due to lack of data for 16 to 18 September at Elfin Cove and Haines, and 17 to 18 September for Hoonah, these sites were excluded to obtain the fully balanced design required for repeated measures. In cases when 1 out of the 3 traps at a site was non-operational (Echo Cove: 27 and 28 September; Gustavus: 21 to 29 September), only 2 trap values were used. Due to missing data, 22 and 25 September were discarded for the repeated measures analysis. A Bonferroni post-hoc test was used to compare least-squared means for the significant interaction of date and location.

Morphometric variation analyses. We measured carapace length (CL) and width (CW) of all collected megalopae to $0.1 \mathrm{~mm}$ using an ocular micrometer (2005: $\mathrm{n}=268 ; 2006: \mathrm{n}=303)$. CL was defined as the length from the rear of the carapace proximal to the dorsal spine to the tip of the rostral spine; CW was defined as the widest part of the carapace (Debrosse et al. 1990, Sulkin \& McKeen 1996). All measured larvae were freeze dried in a VirTis Freezemobile 12 lyophilizer until they reached a constant weight, and then they were weighed to $0.001 \mathrm{mg}$ using a Cahn C35 ultramicrobalance. CW, CL, and larval dry weight were compared among sites within Berner's Bay in 2005 with a MANOVA. These 3 attributes were also compared among 7 of the 9 sites sampled in September 2006 with a MANOVA, with location as the effect. Due to low sample sizes ( 2 and 3 larvae caught, respectively), the Angoon and Indian Cove sites were excluded from statistical comparisons. Any day when not all sites were sampled was removed from the data set to allow for a balanced design.

\section{RESULTS}

\section{Spatial variation}

We found significant spatial variation in the abundance of megalopae on both local and regional scales in the northern portion of southeastern Alaska. Sampling on a small scale, within Berner's Bay, in 2005

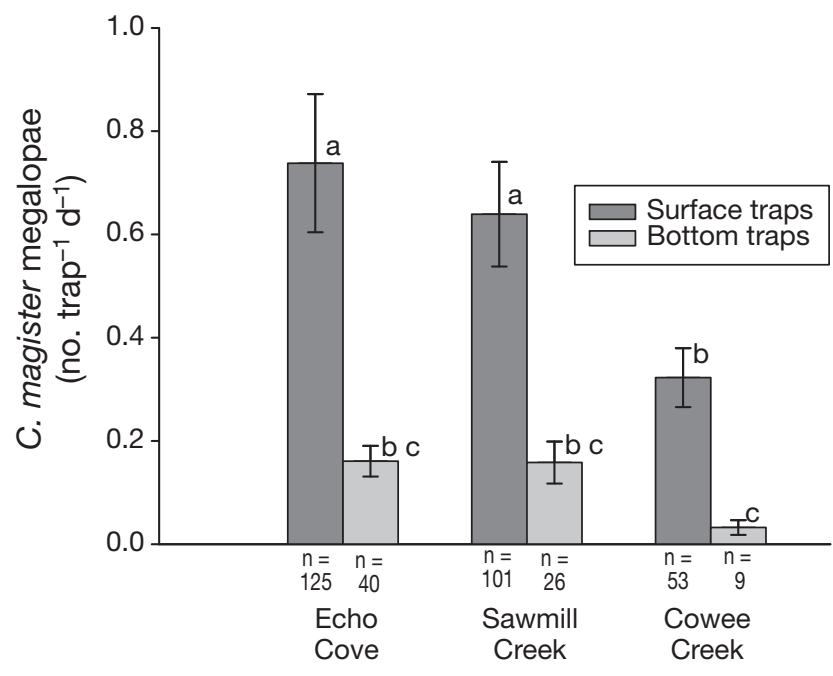

Fig. 2. Cancer magister. Mean $( \pm \mathrm{SE})$ number of megalopae caught per trap per day in surface $(<1 \mathrm{~m}$ depth) and bottom (10 m depth) traps at 3 locations in Berner's Bay in 2005. Dissimilar letters indicate significant differences among sets

revealed that 2 sites (Echo Cove and Sawmill Creek) had significantly more megalopae than the third site (Cowee Creek) (Fig. 2; 2-way ANOVA; location effect: $\mathrm{df}=1 / 893, F=39.77, \mathrm{p}<0.0001)$. We also found variation in capture depth, as surface traps caught approximately 3 times more larvae than bottom traps (Fig. 2; 2-way ANOVA depth effect: $\mathrm{df}=2 / 893, F=7.54, \mathrm{p}=$ 0.0006; depth $\times$ location effect: $\mathrm{df}=5 / 893, F=10.33$, $\mathrm{p}<0.0001)$. On a larger scale, we caught an average of 32.8 times as many megalopae per day in Bartlett Cove $($ mean $=85, \mathrm{SE}=23.55, \mathrm{n}=3740)$ than in Echo Cove $($ mean $=2.59, \mathrm{SE}=0.68, \mathrm{n}=114), 60 \mathrm{~km}$ distant (repeated measures ANOVA; df $=41 / 166, F=29.85$, $p=0.006$ ) from 17 September to 30 October 2005. When comparing abundance on a regional scale among 7 of the 9 sites sampled in September 2006, Bartlett Cove had significantly more larvae per trap per day than any other site (Fig. 3; 1-way ANOVA; df = 8/331, $F=13.24, p<0.0001)$. We found no significant difference in larval abundance among the other 6 sites.

\section{Temporal variation}

We found temporal variation in the abundance of megalopae at sites in the northern portion of southeastern Alaska, on both year and day time scales. Traps in Echo Cove caught significantly more megalopae in $2005\left(\right.$ mean $=0.461 \operatorname{trap}^{-1} \mathrm{~d}^{-1}, \mathrm{SE}=0.021, \mathrm{n}=$ 329) than 2006 (mean $=0.109 \operatorname{trap}^{-1} \mathrm{~d}^{-1}, \mathrm{SE}=0.071, \mathrm{n}=$ 329) (Fig. 4; 2-way ANOVA; df $=1 / 653, F=23.8, p<$ 0.001). Timing of peak abundance for Echo Cove 2006, Bartlett Cove 2005, and Echo Cove 2005 was similar, 


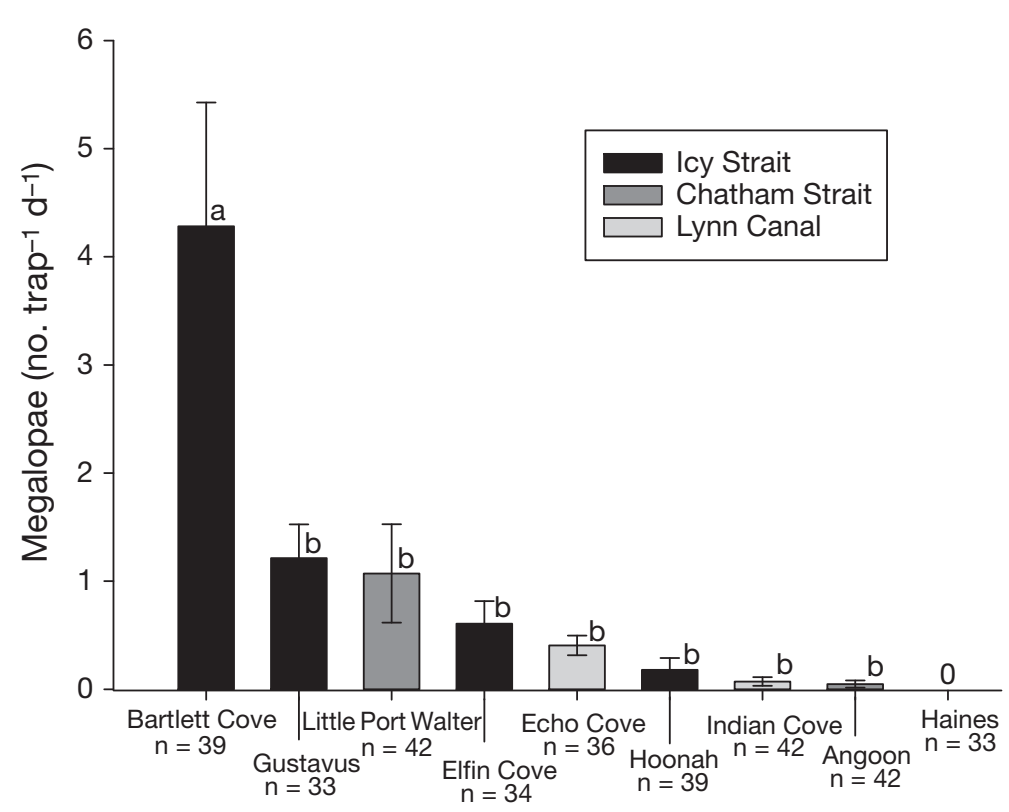

Fig. 3. Cancer magister. Mean $( \pm \mathrm{SE})$ number of megalopae caught per trap per day from 16 to 29 September 2006; n: number of trap days per area. Dissimilar letters indicate significant differences among sets

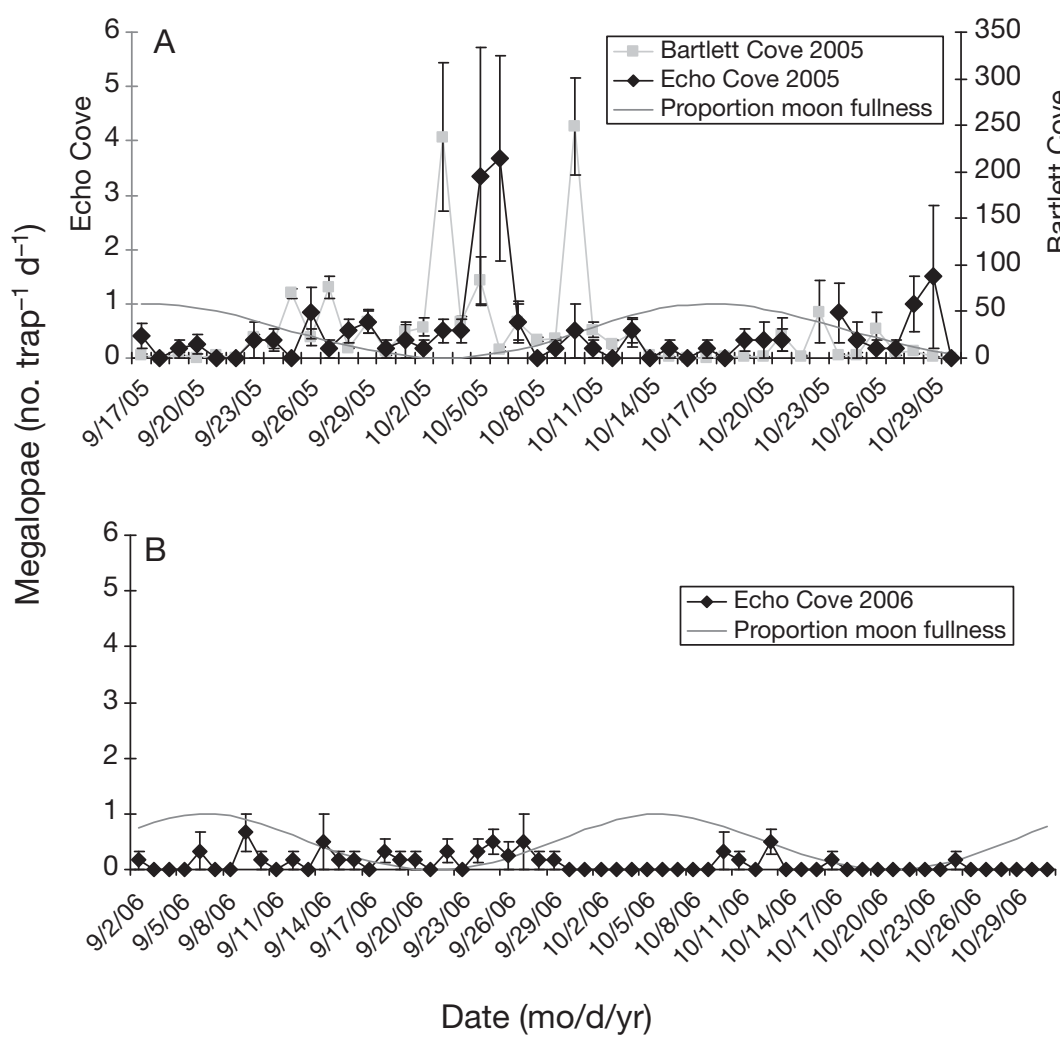

Fig. 4. Cancer magister. Mean $( \pm \mathrm{SE})$ number of megalopae caught per trap per day and moon phase in proportion of fullness in (A) Echo Cove and Bartlett Cove in 2005 and (B) Echo Cove in 2006 with peaks in abundance at both sites and multiple years during the new moon in early October (Table 2, Fig. 4). Although moon fullness seems to be an important factor in larval abundance, we did not have the required time series or sample size to examine this in a statically robust manner. The highest temporal correlation coefficient between Echo Cove and Bartlett Cove in 2005 was at $-5 d(\rho=0.509)$; lags of $+1 d$ $(\rho=0.417)$ and $+2 d(\rho=0.491)$ also had relatively high correlation coefficients (Table 2). When examining spatiotemporal variation among 6 of the 9 sites sampled in September 2006, we found a significant interaction between location and time (Fig. 5; 2-way repeated measures ANOVA; location $\times$ date interaction: $\mathrm{df}=70, F=2.0, \mathrm{p}=$ 0.004). We found no clear overall trend of larvae being caught earlier in the season at sites closer to the outer coast than sites further inland (Fig. 5). On 19 September, significantly more larvae were caught at Little Port Walter than at all other sites (Fig. 5). On 23 September, significantly more larvae were caught at Bartlett Cove and Gustavus than at all other sites (Fig. 5). On 24, 28, and 29 September, significantly more larvae were caught at Bartlett Cove than at all other sites (Fig. 5).

\section{Morphometric variation}

On a small spatial scale, larval size (CW, CL, dry weight) did not differ among sites in Berner's Bay in 2005 (2-way MANOVA; $\mathrm{p}>0.001$ for overall, CW, CL, and dry weight). On a larger scale, among the 9 sites sampled in September 2006, significant differences were observed in all measured characteristics of megalopae (Tables 3 \& 4, Fig. 6). Megalopae from Bartlett Cove had significantly larger CW than at all other sites, an increase of $7.8 \%$ from the group mean, and had a significantly greater CL than at all sites except Elfin Cove (Tables 3 \& 4). Elfin Cove and Hoonah had significantly heavier larvae than at all other sites (Fig. 6). Megalopae sampled at Little Port Walter, the 
Table 2. Cancer magister. Correlation results for temporal lag times in days between Echo Cove and Bartlett Cove in 2005. Data are mean number of megalopae per trap per day. Bold data represent lags with the 3 highest correlation coefficients

\begin{tabular}{|lccc|}
\hline $\begin{array}{l}\text { Bartlett } \\
\text { Cove lag }\end{array}$ & $\begin{array}{c}\text { Start date } \\
\text { Bartlett Cove }\end{array}$ & $\begin{array}{c}\text { Start date } \\
\text { Echo Cove }\end{array}$ & $\begin{array}{c}\text { Correlation } \\
\text { coefficient }\end{array}$ \\
\hline+5 & 17 Sep & 22 Sep & -0.104 \\
+4 & 17 Sep & 21 Sep & -0.141 \\
+3 & 17 Sep & 20 Sep & -0.011 \\
$+\mathbf{+}$ & 17 Sep & $\mathbf{1 9 ~ S e p}$ & $\mathbf{0 . 4 9 1}$ \\
$\mathbf{+ 1}$ & 17 Sep & $\mathbf{1 8 ~ S e p}$ & $\mathbf{0 . 4 1 7}$ \\
0 & 17 Sep & 17 Sep & 0.180 \\
-1 & 17 Sep & 16 Sep & 0.134 \\
-2 & 17 Sep & 15 Sep & -0.004 \\
-3 & 17 Sep & 14 Sep & -0.034 \\
-4 & 17 Sep & 13 Sep & 0.016 \\
$\mathbf{- 5}$ & 17 Sep & $\mathbf{1 2 ~ S e p}$ & $\mathbf{0 . 5 0 9}$ \\
\hline
\end{tabular}

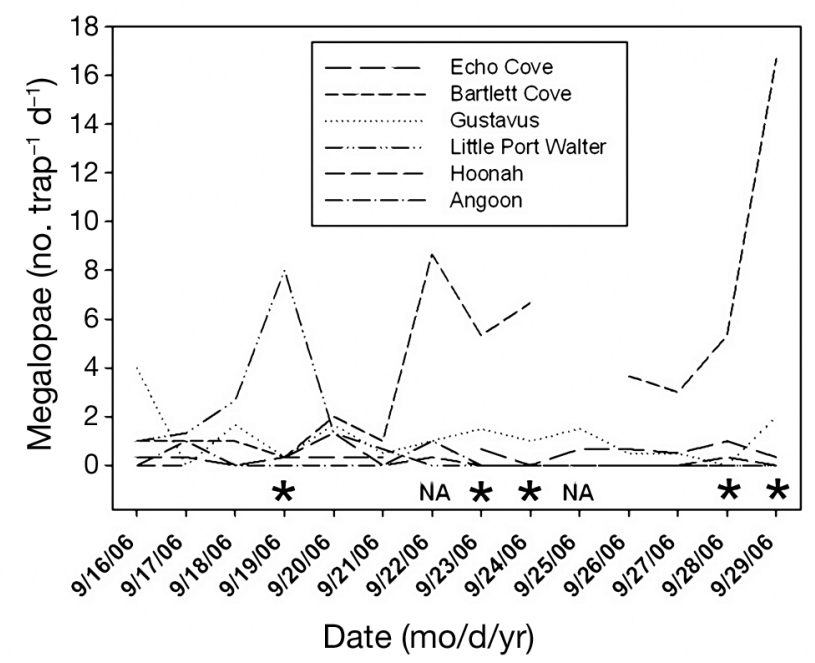

Fig. 5. Cancer magister. Mean number of megalopae caught per trap per day at 6 sites sampled in September 2006. Stars: dates with significant differences in abundance among sites; NA: not analyzed

Table 3. Cancer magister. Summary of MANOVA results with dependent variables carapace length (CL), carapace width (CW), and dry weight by site and by region (for 7 sites and 3 regions sampled in September 2006). $\mathrm{p}<0.0001$ for all variables

\begin{tabular}{|lc|}
\hline Instrumental value & $F$ \\
\hline Overall MANOVA & \\
Wilks' lambda = 0.43 & 83.75 \\
Univariate ANOVA tests — by site & \\
CL & 21.39 \\
CW & 31.87 \\
Dry weight & 14.71 \\
Univariate ANOVA tests - by region & \\
CL & 76.27 \\
CW & 76.91 \\
Dry weight & 39.13 \\
\hline
\end{tabular}

site closest to the outer coast in Chatham Strait, had significantly smaller CW, CL (Tables 3 \& 4), and dry weight (Fig. 6) than at all other sites, decreases of 13.4, 8.2 , and $31 \%$ from the group means, respectively. When the data were generalized by region, we found that larvae caught at sites in the Icy Strait portion had significantly larger CL, CW, and dry weight than those caught in Chatham Strait and Lynn Canal (Table 3).

\section{DISCUSSION}

\section{Spatial variation}

We observed significant variation in the abundance of megalopae on both small and large spatial scales in southeastern Alaska. In both Berner's Bay and Glacier Bay, sites with a higher relative abundance of megalopae were in close vicinity to sites with a lower relative abundance of megalopae. The presence of spatial variation in this region concurs with the findings of Herter \& Eckert (2008). In Berner's Bay in 2005, we found little difference in larval abundance between Echo Cove and Sawmill Creek, 6.4 km distant. However, at Cowee Creek, we caught an average of 2.5 times fewer megalopae per trap per day than in Echo Cove, $2.1 \mathrm{~km}$ distant. This variation among nearby sites was smaller than that found among sites in Glacier Bay, where an average of 21.5 times as many megalopae per trap per day were caught in Bartlett Cove as at a site $13 \mathrm{~km}$ up bay (Herter \& Eckert 2008). Over a larger scale in northern southeastern Alaska, we found higher magnitudes of variation than those observed over smaller scales, with the abundance of megalopae differing from 3.5 to 89.9 times among sites ranging from 21 to $230 \mathrm{~km}$ apart. Bartlett Cove had more larvae than any other site in the present study. Thus, Bartlett Cove may be a relative Dungeness crab Cancer magister larval hot spot and, as such, may be important for long-term monitoring of intra- and inter-annual changes in patterns of the abundance of megalopae.

Numerous explanations for spatial variation in the nearshore abundance of megalopae exist, including transport processes and appropriate settlement habitat. Suitable habitat for Cancer magister settlement is highly abundant in southeastern Alaska, and the habitat in Echo Cove is very similar to that in Bartlett Cove. Thus, we think differential currents and related transport mechanisms resulting from shoreline complexity and high tidal amplitude are a likely explanation for variation in larval abundance. Tidal amplitude in this area of southeastern Alaska is very high, up to $7.3 \mathrm{~m}$, and the currents associated with these large tides can be very strong. Shoreline complexity can exacerbate currents, especially in fjords where a body of water 
Table 4. Cancer magister. Results of least-squared means pairwise differences for carapace width (CW) and carapace length (CL) among sites sampled in September 2006. See Fig. 6 for weight comparisons. Different letters indicate significant differences among sites. Angoon and Indian Cove were excluded from testing due to low sample size $(n<4)$, NA: not analyzed

\begin{tabular}{|c|c|c|c|c|c|c|c|}
\hline \multirow[t]{2}{*}{ Location } & \multirow[t]{2}{*}{$\mathrm{n}$} & \multicolumn{3}{|c|}{$-\mathrm{CW}(\mathrm{mm})$} & \multirow[b]{2}{*}{$\begin{array}{l}\text { Mean } \\
\text { length }\end{array}$} & \multicolumn{2}{|c|}{$\mathrm{CL}(\mathrm{mm})$} \\
\hline & & $\begin{array}{l}\text { Mean } \\
\text { width }\end{array}$ & ${ }_{\mathrm{d}}^{\mathrm{S}}$ & $\begin{array}{l}\text { Site } \\
\text { fference }\end{array}$ & & SE & $\begin{array}{c}\text { Site } \\
\text { difference }\end{array}$ \\
\hline Bartlett Cove & 161 & 3.140 & 0.012 & $\mathrm{a}$ & 6.221 & 0.025 & a \\
\hline Elfin Cove & 20 & 3.010 & 0.042 & $\mathrm{~b}$ & 6.344 & 0.116 & $\mathrm{a}$ \\
\hline Angoon & 2 & 3.164 & 0.000 & NA & 6.019 & 0.000 & NA \\
\hline Gustavus & 40 & 2.981 & 0.042 & $\mathrm{~b}$ & 6.014 & 0.078 & $\mathrm{~b}$ \\
\hline Indian Cove & 3 & 2.967 & 0.032 & NA & 5.801 & 0.185 & NA \\
\hline Hoonah & 7 & 2.920 & 0.066 & $\mathrm{~b}$ & 5.875 & 0.108 & bc \\
\hline Echo Cove & 16 & 2.938 & 0.042 & $\mathrm{~b}$ & 5.767 & 0.080 & $\mathrm{C}$ \\
\hline Little Port Walter & 20 & 2.644 & 0.032 & $\mathrm{C}$ & 5.425 & 0.077 & $\mathrm{~d}$ \\
\hline
\end{tabular}

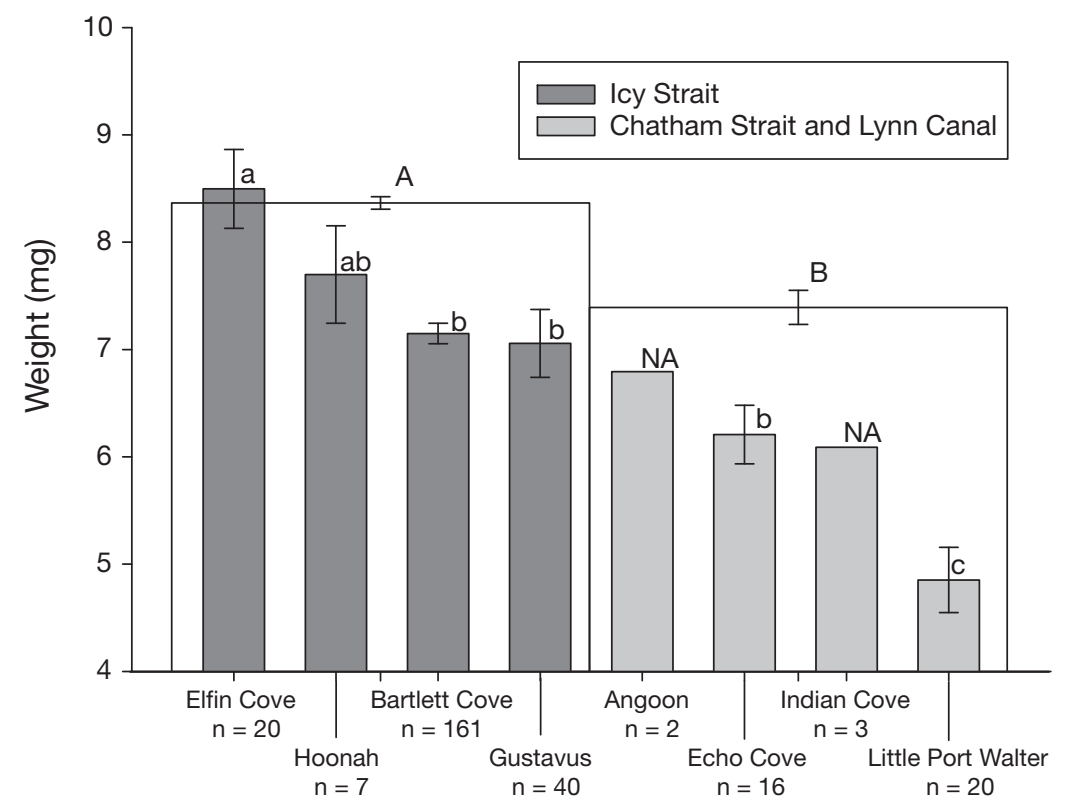

Fig. 6. Cancer magister. Mean $( \pm \mathrm{SE})$ dry weights of megalopae caught at each site, and by major waterway, showing a potential barrier to larval transport (hollow bars) from 16 to 29 September 2006. Dissimilar letters indicate significant differences among sites. Due to low sample size $(n<4)$, the Angoon and Indian Cove sites were excluded from statistical testing (NA: not analyzed)

$90 \mathrm{~km}$ long may have a mouth $2.5 \mathrm{~km}$ wide, as is the case for Lynn Canal. Thus, abundance hot spots may be areas, such as small embayments, where currents slow sufficiently to allow larvae to aggregate.

We caught a significantly higher abundance of megalopae in surface traps than in traps at $10 \mathrm{~m}$ depth in Berner's Bay in both study years, suggesting that larvae may be transported in surface waters, where they would be available for transport by physical forcing mechanisms (Epifanio 1988, McConaugha 1988). These megalopae in southeastern Alaska may be utilizing selective tidal stream transport to reinvade estu- aries in order to settle in suitable habitat, as has been suggested by Fisher (2006) and Herter \& Eckert (2008). Other explanations for the greater abundance of megalopae at the surface than near the bottom include megalopae remaining in the surface waters at all times or vertical migration. However, if larvae remained at the surface at all times, they would be flushed away from settlement habitat with each ebbing tide, which has not previously been observed for Cancer magister megalopae in estuarine areas. Diel vertical migration, wherein the larvae rise to the surface during the dark hours (Shanks 1986, 1995b), may result in reduced risk of predation (Dini \& Carpenter 1988, Olmi 1994). However, diel vertical migration could also result in individuals being advected away from settlement habitat. Although these explanations seem unlikely, they cannot be discounted since we sampled light traps at intervals that combined multiple tidal regimes, and light traps likely only effectively sample in the dark (Lindquist \& Shaw 2005).

\section{Temporal variation}

Our results from Berner's Bay and Bartlett Cove in 2005 indicate that larvae reinvade the estuary as megalopae prior to settling. Megalopae arrived in high abundance over short periods of time, with low catches between high abundance pulses. If larvae were retained in Berner's Bay and Bartlett Cove, we would expect relatively constant light-trap catches, as no limitation by transport mechanisms would affect the larvae. Thus, the observed pulse patterns suggest that megalopae reenter the bay during limited time periods. The pulses in the abundance of megalopae observed in Echo Cove in 2005 may be related to moon phase, suggesting that Cancer magister megalopae may reinvade estuaries on high tides during new moons. This finding agrees with the results of Eggleston \& Armstrong (1995), who noted large pulses of megalopae moving into estuaries during new moon. Christy \& Morgan (1998) found that megalopae of $9 \mathrm{crab}$ taxa immigrated at night and primarily on large amplitude flood tides, 
with few megalopae entering the water column on the large amplitude diurnal or semidiurnal flood tides; hence, they did not maximize their rate of up-estuary movement. One explanation for these, and our, results is that Selective Tidal Stream Transport behavior is modified by decreased risk of predation during nocturnal hours (Dini \& Carpenter 1988, Olmi 1994), as the combination may increase fitness as a result of reduced risk of predation. Thus, pulses of megalopae may differentially come into estuaries on high-amplitude tides during new moon due to increased darkness.

We found a significant relationship in the abundance of megalopae over time between Bartlett Cove and Echo Cove; with the highest correlation when catches in Bartlett Cove were lagged $5 \mathrm{~d}$ behind Echo Cove. However, this pathway seems counterintuitive. Based on the findings of many studies off the coast of the contiguous United States, it is unlikely that larvae are moving from an area inland to an area offshore during the settlement time period. We also found significant correlations when Echo Cove was lagged 1 and $2 \mathrm{~d}$ behind Bartlett Cove, possibly indicating an outercoast to inside-waters transport mechanism; however, we find this to be unlikely due to the distance between the sites ( 120 km via water) and the short time frame, which would require the larvae to have a sustained average speed of $3.5 \mathrm{~km} \mathrm{~h}^{-1}$. On the larger spatial scale, we found significant variation in the abundance of megalopae over time by location during the $2 \mathrm{wk}$ study in September 2006; however, there was no clear spatial pattern from offshore to inland waters and no evidence of a pulse of megalopae moving from one area to another. Our results should be interpreted with caution, as the 2006 regional study was only conducted for $2 \mathrm{wk}$, and, thus, we cannot extrapolate to temporal abundance patterns for the region over the entire settlement period; however, the $2 \mathrm{wk}$ of the study did coincide with a large pulse of megalopae in the 2006 time series (G. L. Eckert unpubl. data).

Differences in spatial, temporal, and morphometric variations in megalopae between sites suggests the possibility of multiple transport pathways for Cancer magister larvae in southeastern Alaska. Our observations of higher abundance and larger sizes and weights suggest that larvae in Icy Strait may be transported differently than those in Lynn Canal and Chatham Strait. Few studies have investigated water flow in southeastern Alaska (Weingartner et al. 2009), though a hydrographic model supports this hypothesis (Hill et al. 2009). Hill et al. (2009) used a highly resolved ADCIRC (ADvanced CIRCulaton) computer simulation of the hydrodynamics in Glacier Bay, which incorporates tides, winds, and freshwater inflows to create depthintegrated velocity fields and resultant particle tracks. By examining these particle tracks, Hill et al. (2009) found a front located just to the east of the mouth of Glacier Bay, which may restrict water mixing between the central and eastern Icy Strait. This front is stronger to the north of Icy Strait, nearer the mouth of Glacier Bay, and weaker on the south side of Icy Strait, where normal linear tidal movement was observed. Thus, the Hill et al. (2009) model may explain the increased abundance of megalopae that we found in Bartlett Cove; megalopae moving through northern and middle Icy Strait could hit this front and be impeded from further eastern movement, and these larvae could then be flushed into Bartlett Cove by tidal exchange. In contrast, only larvae traveling through the southern portion of Icy Strait would be able to be carried by tidal exchange beyond this barrier area. The fronts observed in the Hill et al. (2009) model in Icy Strait may not be uncommon throughout southeastern Alaska, because of the complex shoreline and strong tidal currents in this region (Weingartner et al. 2009).

\section{Morphometric variation}

The mean sizes of megalopae in the present study were equal to or greater than those reported for locations in British Columbia and Washington. The mean CL values of megalopae in Georgia Strait, the Strait of Juan de Fuca, and Anacortes (DeBrosse et al. 1990) were smaller than those reported here, and the mean CL values of megalopae from Grays Harbor and Vancouver Island (Debrosse et al. 1990) were similar to ours from Icy Strait. The weights of megalopae we found were as much as 6.7 times larger than those reported by Sulkin \& McKeen (1996). However, because the larvae weighed by Sulkin \& McKeen (1996) were laboratory-reared, this comparison should be considered with caution and may reflect a laboratory versus field pattern rather than a geographical pattern.

Temperature affects Cancer magister larval growth rates (Reed 1969, Sulkin \& McKeen 1989, Sulkin \& McKeen 1994), with cooler water temperatures causing slower development rates, increasing the duration of larval stages (Shirley et al. 1987, Moloney et al. 1994), which results in geographic variation in timing of development (Reed 1969). Cooler water temperatures produce larger zoeae (Shirley et al. 1987, Moloney et al. 1994). However, the relationship between larval size and temperature is not always clear; C. magister megalopae in the warmer offshore coastal waters of Washington are larger and heavier than those of the cooler inland waters of Puget Sound (Orensanz \& Gallucci 1988, Dinnel et al. 1993, Sulkin \& McKeen 1996). Puget Sound is characterized by low initial temperatures that steadily increase during larval development, while offshore water temperatures tend 
to be warmer, more moderate, and stable (Sulkin et al. 1996). These weight and size differences between larvae in Puget Sound and offshore waters have led some to suggest the presence of a distinctive inland-water population of C. magister (Orensanz \& Gallucci 1988, Debrosse et al. 1990, Dinnel et al. 1993).

One explanation for the larger sizes and weights seen in megalopae from southeastern Alaska compared to areas further south and for the variation within southeastern Alaska is the exposure to cooler temperature regimes during early ontogeny. When zoeae hatch in mid-February in Puget Sound (Armstrong \& Gunderson 1985) the water temperature is $\sim 6.5-7^{\circ} \mathrm{C}$ and steadily increases to $\sim 11-11.5^{\circ} \mathrm{C}$ during the ontogenetic period (Sulkin \& McKeen 1996). In the inside waters of southeastern Alaska, peak hatching occurs in May and June (Shirley et al. 1987) into water averaging between $\sim 6$ and $\sim 7.5^{\circ} \mathrm{C}$ in Glacier Bay (Etherington et al. 2007). Water temperature then increases to $\sim 8.5^{\circ} \mathrm{C}$ in July and drops to $\sim 8^{\circ} \mathrm{C}$ by September and $\sim 7.5^{\circ} \mathrm{C}$ by October (Etherington et al. 2007), the months of peak settlement. Thus, larvae developing in the inland waters of southeastern Alaska may be exposed to cooler temperatures over more of their ontogeny than those in Puget Sound. Offshore waters of southeastern Alaska are generally warmer than waters within the inside passages. Water temperatures at the Fairweather buoy off the coast of southeastern Alaska $\left(58.243^{\circ} \mathrm{N}, 137.993^{\circ} \mathrm{W}\right)$ average $\sim 6$ to $8^{\circ} \mathrm{C}$ in April and May, increase sharply to $\sim 15^{\circ} \mathrm{C}$ by August, then decrease to a mean of $\sim 13^{\circ} \mathrm{C}$ in September and $\sim 11.5^{\circ} \mathrm{C}$ in October (NODC 2007). Though larvae hatching in both the inside waters and on the outer coast of southeastern Alaska would initially be exposed to similar temperatures, those in the outside waters would experience warmer temperatures during middle and late ontogeny.

In southeastern Alaska, sites located in Icy Strait had significantly larger and heavier individuals than sites located in Chatham Strait and Lynn Canal. This difference between waterways may indicate the presence of spatially separate inland and outer coast populations of Cancer magister in southeastern Alaska, as has been proposed for the Puget Sound area (Orensanz \& Gallucci 1988, Debrosse et al. 1990, Jamieson \& Armstrong 1991, Dinnel et al. 1993, Jamieson \& Phillips 1993, McMillan et al. 1995), where megalopae from the outer coast are distinctive because of their substantially larger size (Orensanz \& Gallucci 1988, Debrosse et al. 1990, Dinnel et al. 1993). Southeastern Alaska experiences temperature patterns similar to the Puget Sound region; thus, similar variation in temperature regimes during larval ontogeny may explain differences in the sizes of megalopae observed among sites in the present study. Another possible explana- tion is that the type and availability of prey may be contributing factors to differences in C. magister larval size between geographic locations (Dinnel et al. 1993). C. magister larvae in southeastern Alaska have longer larval durations than those in more southern populations, which may provide more time for larvae to feed. The highly productive and nutrient-rich waters in southeastern Alaska may provide more and/or higher quality feeding, which may contribute to the increased size and weight we found in these more northern populations. Our findings of smaller size and weight in the inside waters of southeastern Alaska may indicate that C. magister larvae in Lynn Canal and Chatham Strait are retained in the inside waters during ontogeny, while those in Icy Strait are advected to the Gulf of Alaska and subsequently return. However, due to the nature of this study and the brief time that most sites were sampled, any discussion of this possibility is merely conjecture, and further study is needed.

\section{CONCLUSIONS}

In conclusion, we found high spatial variation in the abundance of Dungeness crab Cancer magister megalopae on both small and regional scales in the northern portion of southeastern Alaska. Sites at relatively close proximity to each other had significantly different abundances of megalopae. C. magister megalopae were caught in significantly higher numbers in surface traps, which may indicate that they are being transported in the faster-moving surface waters. The abundance of megalopae was higher in Icy Strait, which contained 3 out of 4 of the highest abundance sites, than at sites in Chatham Strait or Lynn Canal. This variation may be a result of differential hydrodynamic processes that affect larval transport. Due to the spatial variation in abundance, the morphometric variation found in larvae of $C$. magister, the lack or ordered pulse arrival times, and the potentially isolating currents proposed by computer simulation, populations in Chatham Strait and Lynn Canal may be utilizing a transport pathway separate from those in Icy Strait. Further investigation is needed to better understand larval connectivity of $C$. magister in southeastern Alaska and its potential effects on adult populations and commercial fisheries.

Our findings on larval transport pathways and spatial, temporal, and morphometric variations are broadly applicable to other nearshore marine and estuarine systems. Even though the level of oceanographic complexity found in southeastern Alaska may be unique, the role of larval behavior combined with oceanographic factors, such as the timing of the spring transition of the California Current (Shanks \& Roegner 
2007), still plays a pivotal role in larval transport. These factors are widely found and drive many transport processes, including whether larvae are retained nearshore or are transported offshore and then migrate back onshore (Shanks \& Wright 1987, Morgan \& Christy 1995, Botsford et al. 1998, Botsford 2001, Epifanio \& Garvine 2001, Shanks \& Eckert 2005, Park et al. 2007, Roegner et al. 2007, Herter \& Eckert 2008, Morgan et al. 2009a,b).

Acknowledgements. We thank the Alaska Department of Fish and Game Nearshore Marine Research VII Grant for funding this work. We thank N. Hillgruber, J. Taggart, P. Barry, $\mathrm{H}$. Herter, and J. Webb for their help with the project and their advice and edits to this manuscript. Special thanks to D. Cosby, M. Fontenot, P. Malecha, B. McLuckie, J. Parkin, W. Rapp, G. Wrobel, the staff of the NOAA Little Port Walter field station, and the 65+ high school students who collected samples and made this project possible. We thank L. Hayes and G. Hazelton of the University of Alaska Fairbanks for their help with project logistics, as well as 3 anonymous reviewers, whose comments greatly improved this manuscript.

\section{LITERATURE CITED}

Armstrong DA, Gunderson DR (1985) The role of estuaries in Dungeness crab early life history: a case study in Grays Harbor, Washington. In: Proceedings of the Symposium on Dungeness crab biology and management. Anchorage Sea Grant Rep 85, University of Alaska Fairbanks, Fairbanks, AK, p 145-170

Botsford LW (2001) Physical influences on recruitment to California Current invertebrate populations on multiple scales. ICES J Mar Sci 58:1081-1091

Botsford LW, Moloney CL, Largier JL, Hastings A (1998) Metapopulation dynamics of meroplanktonic invertebrates: the Dungeness crab Cancer magister as an example. In: Jamieson G, Campbell A (eds) Proceedings of the North Pacific symposium on invertebrate stock assessment and management. Can Spec Publ Fish Aquat Sci 125:295-306

Botsford LW, Hastings A, Gaines SD (2001) Dependence of sustainability on the configuration on marine reserves and larval dispersal distance. Ecol Lett 4:114-150

Broitman BR, Blanchette CA, Menge BA, Lubchenco J and others (2008) Spatial and temportal patterns of invertebrate recruitment along the West Coast of the United States. Ecol Monogr 78(3):403-421

Christy JH, Morgan SG (1998) Estuarine immigration by crab post larvae: mechanisms, reliability and adaptive significance. Mar Ecol Prog Ser 174:51-65

DeBrosse G, Sulkin S, Jamieson G (1990) Intraspecific morphological variability in megalopae of three sympatric species of the genus Cancer (Brachyura, Cancridae). J Crustac Biol 10:315-329

Dini ML, Carpenter SR (1988) Variability in Daphnia behavior following fish community manipulations. J Plankton Res 10:621-635

> Dinnel PA, Armstrong DA, McMillan RO (1993) Evidence for multiple recruitment-cohorts of Puget Sound Dungeness crab, Cancer magister. Mar Biol 115:53-63
Eckert GL (2004) Dungeness crab larval and settler abundance in an Alaskan marine reserve. American Society of Limnology and Oceanography Ocean Sciences Conference, Honolulu, HI

Eggleston DB, Armstrong DA (1995) Presettlement and postsettlement determinants of estuarine Dungeness crab recruitment. Ecol Monogr 65:193-216

Eggleston DB, Armstrong DA, Elis WE, Patton WS (1998) Estuarine fronts as conduits for larval transport: hydrodynamics and spatial distribution of Dungeness crab postlarvae. Mar Ecol Prog Ser 164:73-82

Epifanio CE (1988) Dispersal strategies of two species of swimming crab on the continental-shelf adjacent to Delaware Bay. Mar Ecol Prog Ser 49:243-248

Epifanio CE, Garvine RW (2001) Larval transport on the Atlantic continental shelf of North America: a review. Estuar Coast Shelf Sci 52:51-77

Epifanio CE, Tilburg CE (2008) Transport of larval forms near large estuaries of the Middle Atlantic Bight: a wet and windy journey. J Mar Res 66:723-749

Etherington LL, Hooge PN, Hooge ER, Hill DF (2007) Oceanography of Glacier Bay, Alaska: implications for biological patterns in a glacial fjord estuary. Estuar Coast 30:927-944

Fernandez M, Iribarne O, Armstrong D (1994) Swimming behavior of Dungeness crab, Cancer magister dana, megalopae in still and moving water.Estuaries 17:271-275

> Fisher JL (2006) Seasonal timing and duration of brachyuran larvae in a high-latitude fjord. Mar Ecol Prog Ser 323:213-222

> Herter HL, Eckert GL (2008) Transport of Dungeness crab (Cancer magister) megalopae into Glacier Bay, Alaska. Mar Ecol Prog Ser 372:181-194

Hill DF, Ciavola SJ, Etherington L, Klaar MJ (2009) Estimation of freshwater runoff into Glacier Bay, Alaska and incorporation into a tidal circulation model. Estuar Costal Shelf Sci 82:95-107

Hobbs RC, Botsford LW, Thomas A (1992) Influence of hydrographic conditions and wind forcing on the distribution and abundance of Dungeness crab, Cancer magister, larvae. Can J Fish Aquat Sci 49:1379-1388

Incze L, Xue HJ, Wolff N, Xu D and others (2010) Connectivity of lobster (Homarus americanus) populations in the coastal Gulf of Maine: Part II. Coupled biophysical dynamics. Fish Oceanogr 19:1-20

Jamieson GS, Armstrong DA (1991) Spatial and temporal recruitment patterns of Dungeness crab in the northeast Pacific. Mem Queensl Mus 31:365-381

Jamieson GS, Phillips AC (1988) Occurrence of Cancer crab (Cancer magister and Cancer oregonensis) megalopae off the west-coast of Vancouver Island, British Columbia. Fish Bull 86:525-542

> Jamieson GS, Phillips A (1993) Megalopal spatial-distribution and stock separation in Dungeness crab (Cancer magister). Can J Fish Aquat Sci 50:416-429

Jamieson GS, Phillips AC, Huggett WS (1989) Effects of ocean variability on the abundance of Dungeness crab (Cancer magister) megalopae. In: Beamish RJ, McFarlane GA (eds) Effects of ocean variability on recruitment and an evaluation of parameters used in stock assessment models. Can Spec Publ Fish Aquat Sci 108:305-325

Johnson J, Shanks AL (2002) Time series of the abundance of the post-larvae of the crabs Cancer magister and Cancer spp. on the southern Oregon coast and their cross-shelf transport. Estuaries 25:1138-1142

Lindquist DC, Shaw RF (2005) Effects of current speed and 
turbidity on stationary light-trap catches of larval and juvenile fishes. Fish Bull 103:438-444

Lough GR (1974) Dynamics of crab larvae (Anomura, Brachyura) off the central Oregon coast, 1969-1971. PhD dissertation, Oregon State University, Corvallis, OR

McConaugha JR (1988) Export and reinvasion of larvae as regulators of estuarine decapod populations. Am Fish Soc Symp 3:90-103

McMillan RO, Armstrong DA, Dinnel PA (1995) Comparison of intertidal habitat use and growth rates of two northern Puget Sound cohorts of 0+ age Dungeness crab, Cancer magister. Estuaries 18:390-398

Miller JA, Shanks AL (2004) Ocean-estuary coupling in the Oregon upwelling region: abundance and transport of juvenile fish and of crab megalopae. Mar Ecol Prog Ser 271:267-279

> Moloney CL, Botsford LW, Largier JL (1994) Development, survival and timing of metamorphosis of planktonic larvae in a variable environment - the Dungeness crab as an example. Mar Ecol Prog Ser 113:61-79

Morgan SG, Christy JH (1995) Adaptive significance of the timing of larval release by crabs. Am Nat 145:457-479

Morgan SG, Fisher JL (2010) Larval behavior regulates nearshore retention and offshore migration in an upwelling shadow along the open coast. Mar Ecol Prog Ser 404: 109-126

Morgan SG, Zimmer-Faust RK, Heck KL Jr, Coen LD (1996) Population regulation of blue crabs Callinectes sapidus in the northern Gulf of Mexico: postlarval supply. Mar Ecol Prog Ser 133:73-88

Morgan SG, Fisher JL, Mace AJ, Akins L, Slaughter AM, Bollens SM (2009a) Cross-shelf distributions and recruitment of crab postlarvae in a region of strong upwelling. Mar Ecol Prog Ser 380:173-185

Morgan SG, Fisher JL, Miller SH, McAfee ST, Largier JL (2009b) Nearshore larval retention in a region of strong upwelling and recruitment limitation. Ecology 90: 3489-3502

NODC (National Oceanographic Data Center) (2007) Interactive data access and retrieval system. NODC. Available at: www.nodc.noaa.gov/dsdt/index.html (accessed 14 August 2007)

Olaguer-Feliu AO, Flores AAV, Queiroga H, GonzalezGordillo JI (2010) Shelf and estuarine transport mechanisms affecting the supply on competent larvae in a suite on brachyuran crabs with different life histories. Mar Ecol Prog Ser 410:125-141

Olmi EJ (1994) Vertical migration of blue crab Callinectes sapidus megalopae - implications for transport in estuaries. Mar Ecol Prog Ser 113:39-54

> Orensanz JM, Gallucci VF (1988) Comparative-study of postlarval life history schedules in four sympatric species of Cancer (Decapoda, Brachyura, Cancridae). J Crustac Biol 8:187-220

Park W, Douglas DC, Shirley TC (2007) North to Alaska: evidence for conveyor belt transport of Dungeness crab larvae along the west coast of the United States and Canada. Limnol Oceanogr 52:248-256

Parrish RH, Nelson CS, Bakun A (1981) Transport mechanisms and reproductive success of fishes in the California Current. Biol Oceanogr 1:175-203

Porter SS, Eckert GL, Byron CJ, Fisher JL (2008) Comparison of light traps and plankton tows for sampling brachyuran crab larvae in an Alaskan fjord. J Crustac Biol 28:175-179

Queiroga H, Costlow JD, Moreire MH (1997) Vertical migration of the crab Carcinus maenas first zoea in an estuary: implications for tidal stream transport. Mar Ecol Prog Ser 149:121-132

Reed PH (1969) Culture methods and effects of temperature and salinity on survival and growth of Dungeness crab (Cancer magister) larvae in the laboratory. J Fish Res Board Can 26:389-397

Reilly PN (1983) Dynamics of Dungeness crab Cancer magister larvae off central and northern California. In: Wild PW, Tasto RN (eds) Life history environment, and mariculture studies of the Dungeness crab Cancer magister, with emphasis on the Central California fishery resource. Calif Dep Fish Game Bull 172:57-84

Roegner GC, Armstrong DA, Shanks AL (2007) Wind and tidal influences on larval crab recruitment to an Oregon estuary. Mar Ecol Prog Ser 351:177-188

Roughgarden J, Gaines S, Possingham H (1988) Recruitment dynamics in complex life cycles. Science 241:1460-1466

Shanks AL (1986) Vertical migration and cross-shelf dispersal of larval Cancer spp. and Randallia ornata (Crustacea, Brachyura) off the coast of southern California. Mar Biol 92:189-199

Shanks AL (1995a) Mechanisms of cross-shelf dispersal of larval invertebrates and fish. In: McEdward L (ed) Ecology of marine invertebrate larvae. CRC Press, New York, NY, p 323-365

> Shanks AL (1995b) Orientated swimming by megalopae of several eastern North Pacific crab species and its potential role in their onshore migration. J Exp Mar Biol Ecol 186: $1-16$

Shanks A (2001) An identification guide to the larval marine invertebrates of the Pacific Northwest. Oregon State University Press, Corvallis, OR

Shanks AL, Eckert GL (2005) Population persistence of California Current fishes and benthic crustaceans: a marine drift paradox. Ecol Monogr 75:505-524

Shanks AL, Roegner GC (2007) Recruitment limitation in Dungeness crab populations is driven by variation in atmospheric forcing. Ecology 88:1726-1737

Shanks AL, Wright WG (1987) Internal-wave-mediated shoreward transport of cyprids, megalopae, and gammarids and correlated longshore differences in the settling rate of intertidal barnacles. J Exp Mar Biol Ecol 114:1-13

Shirley SM, Shirley TC, Rice SD (1987) Latitudinal variation in the Dungeness crab, Cancer magister-zoeal morphology explained by incubation temperature. Mar Biol 95: 371-376

Sulkin SD, McKeen GL (1989) Laboratory study of survival and duration of individual zoeal stages as a function of temperature in the brachyuran crab Cancer magister. Mar Biol 103:31-37

Sulkin SD, McKeen G (1994) Influence of temperature on larval development of four co-occurring species of the brachyuran genus Cancer. Mar Biol 118:593-600

Sulkin SD, McKeen GL (1996) Larval development of the crab Cancer magister in temperature regimes simulating outercoast and inland-water habitats. Mar Biol 127:235-240

Sulkin SD, Mojica E, McKeen GL (1996) Elevated summer temperature effects on megalopal and early juvenile development in the Dungeness crab, Cancer magister. Can J Fish Aquat Sci 53:2076-2079

Thomson RE, Hickey BH, Leblond PH (1989) The Vancouver Island coastal current: fisheries barrier and conduit. In: Beamish RJ, McFarlane GA (eds) Effects of ocean variability on recruitment and evaluation of parameters used in stock assessment models. Can Spec Publ Fish Aquat Sci 108:265-296 
Ware DM, McFarlane GA (1989) Fisheries production domains in the Northeast Pacific Ocean. In: Beamish RJ, McFarlane GA (eds) Effects of ocean variability on recruitment and evaluation of parameters used in stock assessment models. Can Spec Publ Fish Aquat Sci 108:359-379

Weingartner T, Eisner L, Eckert GL, Danielson S (2009) Southeast Alaska: oceanographic habitats and linkages.

Editorial responsibility: Steven Morgan,

Bodega Bay, California, USA
J Biogeogr 36(3):387-400

Xue HJ, Incze L, Xu D, Wolff N, Pettigrew N (2008) Connectivity of lobster populations in the coastal Gulf of Maine. I. Circulation and larval transport potential. Ecol Model 210:193-211

Yoshioka PM (1982) Role of planktonic and benthic factors in the population dynamics of the bryozoans Membranipora membranacea. Ecology 63:457-468

Submitted: January 4, 2011; Accepted: February 24, 2011

Proofs received from author(s): May 6, 2011 